\title{
POLEMIKA JÓZEFA TISCHNERA Z TRADYCJA TOMISTYCZNĄ JAKO SPÓR O KSZTAŁT WSPÓŁCZESNEJ EDUKACJI RELIGIJNEJ W POLSCE
}

Streszczenie: Przedmiotem niniejszego tekstu jest prezentacja fragmentu jednego z najciekawszych sporów filozoficzno-religijnych między ks. Józefem Tischnerem a przedstawicielami szkoły tomistycznej w Polsce. Poniższa analiza skupiała się wyłącznie na pierwszej fazie sporu (1968-1972), podstawowym celem opracowania jest jednak wydobycie głosów krytyki kluczowych w obecnie toczącej się dyskusji nad kształtem współczesnej edukacji religijnej w Polsce, jak również dostrzeżenie ważnych argumentów w tej kwestii. Zdaniem autora niniejszego opracowania, ukazanie struktury filozoficzno-teologicznego sporu doprowadzić ma do odsłonięcia kontekstu edukacyjnego, który lokuje tę dyskusję $\mathrm{w}$ przestrzeni krytycznych analiz pedagogiczno-religijnych.

Słowa kluczowe: Józef Tischner; tomizm; neotomizm; filozofia chrześcijańska; edukacja religijna; krytyczna pedagogika religii.

\section{Wstęp}

Przedmiotem niniejszego tekstu jest prezentacja pierwszej części jednego z najciekawszych sporów filozoficzno-religijnych powojennej Polski ${ }^{1}$. Polemika ta zapoczątkowana w latach 6o. XX wieku przez ks. Józefa Tischnera objęła swoim zasięgiem niemal wszystkie liczące się ówcześnie ośrodki filozoficzne. Dotyczyła kształtu, struktury oraz języka przekazu treści religijnych w tradycji katolickiej, w której jedną z najważniejszych koncepcji odgrywała filozofia św. Tomasza z Akwinu, będąca podwaliną dla klasycznej szkoły filozofii tomistycznej. Omawiana dyskusja rozpoczyna się od niejednorodnej oceny wpływu filozofii na współczesną myśl

1 Całość sporu Józefa Tischnera z przedstawicielami polskiego tomizmu w latach 1967-1980 w perspektywie badań w zakresie polskiej pedagogiki religii jest aktualnie opracowywana przez autora tego artykułu. 
chrześcijańską. Relacja między filozofią a doktryną katolicką stała się elementem różnicującym nie tylko w aspekcie interpretacji treści przekazu, lecz także samej roli i miejsca filozofii w tejże przestrzeni. Polaryzacja stanowisk najbardziej uwidoczniła się między tomistyczną a poza-tomistyczną filozofią chrześcijańską. Bezpośrednim przykładem takiej rozbieżności były opozycyjne stanowiska ks. Józefa Tischnera oraz przedstawicieli szkoły tomistycznej w Polsce.

Józef Tischner, zaliczany do grona fenomenologów i filozofów dialogu, czerpał problematykę badawczą z myśli klasycznej, jednak strukturę i metodę opisu opierał na filozofii współczesnej, szczególnie na egzystencjalizmie, fenomenologii, hermeneutyce czy filozofii dialogu (Bonowicz 2002; Tischner 2002; Wadowski 1999) ${ }^{2}$. Natomiast według Jarosława Horowskiego (2015, s. 35-42) ${ }^{3}$ głównymi przedstawicielami szkoły tomistycznej byli w omawianym czasie: Mieczysław A. Krąpiec, Antoni B. Stępień, Mieczysław Gogacz, Jerzy Turowicz, Stefan Swieżawski (Tischner 2002). Tradycja ta - dziś bardzo zróżnicowana - źródłowo swoją metafizykę i teorię poznania wywodzi z filozofii św. Tomasza z Akwinu, który bezpośrednio odwoływał się do klasycznej filozofii Arystotelesa (Horowski 2015, s. 57-139).

Poniższa analiza skupia się wyłącznie na pierwszej fazie sporu Tischnera z polskim tomizmem. Podstawowym celem pracy jest wydobycie głosów krytyki kluczowych w obecnie toczącej się dyskusji nad kształtem współczesnej edukacji religijnej w Polsce, jak również dostrzeżenie ważnych argumentów w tej kwestii. Innymi słowy, chodzi o jednoczesne ukazanie wymiaru filozoficzno-teologicznego oraz uwidocznienie kontekstu edukacyjnego, który może lokować tę dyskusję w przestrzeni krytycznych analiz pedagogiczno-religijnych. W literaturze przedmiotu spór ten został już dość wnikliwie zbadany na wielu płaszczyznach, co pozwoliło na przybliżenie zwłaszcza intelektualnego klimatu tamtego okresu oraz przedmiotu dyskusji wokół filozofii, aksjologii i antropologii chrześcijańskiej (Dymarski 1998, s. 235-245; Gabrysz 2013, s. 3-19; Horowski 2008, s. 241-255; Jawor 2013, s. 211-227; Szary 2014, s. 221-247; Wilczek 2009, s. 52-72; Zambrzuski 2012, s. 99-114). W tym przypadku cel jest nieco inny. Jest nim przede wszystkim próba ukazania, na ile problematyka i przedmiot dyskusji mogą przełożyć się na szersze rozumienie dzisiejszego sporu toczącego się wokół edukacji religijnej w Polsce.

2 Od strony metodologicznej należy tu wymienić: egzystencjalizm Martinia Heideggera, fenomenologię Edmunda Husserla i Romana Ingardena, hermeneutykę Paula Ricoeura oraz filozofię dialogu Emanuela Levinasie.

3 Szkoła tomistyczna nie jest tym samym co szkoła klasyczna. Szkoła klasyczna zakresowo jest kierunkiem dużo szerszym, wywodzącym się z filozofii Arystotelesa, szkoła tomistyczna jest natomiast kierunkiem pochodzącym od św. Tomasza, który zainspirowany był myślą Arystotelesa i posłużył się nią do opisu Objawienia chrześcijańskiego. 


\section{Spór na gruncie filozofii i teologii}

W drugiej połowie lat 6o. XX wieku J. Tischner opublikował na łamach miesięcznika „Znak” dwa artykuły: W kręgu spraw psychologii i filozofii (1967, s. 80-105) i Prolegomena chrześcijańskiej filozofi śmierci (1968, s. 422-440). W publikacjach tych można odnaleźć próbę określenia współczesnej myśli zarówno filozoficznej, jak i teologicznej, a także ocenę tego stanu rzeczy. Liczne argumenty pochodzące $z$ analiz fenomenologicznych Martina Heideggera czy Edmunda Husserla ukazuja kwestie dobra, zła, wolności i śmierci człowieka w świetle dalekim od klasycznego (tomistycznego) ujęcia. Przykładowo, zawarta w tekstach perspektywa umierania oraz kwestia kontaktu człowieka ze śmiercią koncentrują się przede wszystkim na wewnętrznych, indywidualnych doświadczeniach jednostki. W ten oto sposób autor zmienia płaszczyznę analiz z metafizycznej na fenomenologiczną. Wiąże się to bezpośrednio z ogólną oceną tomizmu, która zdaniem Tischnera nie tylko nie jest pozytywna, lecz wręcz konieczna do pilnego przedefiniowania i rekonstrukcji (Tischner 1968, s. 432-440).

Wymienione powyżej opracowania nie stały się jednak początkiem jawnej i otwartej dyskusji. W tym samym czasie środowisko tomistów publikuje kilka tekstów, również na łamach miesięcznika „Znak”, o stosunku tomizmu do współczesnej filozofii, teologii i chrześcijaństwa. Jednym z nich jest artykuł M. A. Krąpca, w którym autor kreśli granice między nauką, filozofią a teologią (1967, s. 861-887). Nauka prezentowana jest jako zupełnie autonomiczna dziedzina życia ludzkiego, niezależna, niesprzeczna z filozofią czy wiarą. Natomiast wiara i system filozoficzny niekiedy wydają się być ze sobą dość mocno splecione. To połączenie następuje z inicjatywy wiary - Objawienia, które potrzebuje teorii czy systemu, aby móc się całościowo i spójnie prezentować. Chrześcijaństwo, przyjmując klasyczną koncepcję bytu oraz racjonalność filozofii tomistycznej w sposób pełny nabrało cech holistycznego systemu. Tym samym ani ze strony nauki, ani tym bardziej filozofii nie może być w stosunku do wiary jakichkolwiek sprzeczności. W samej treści nauka i teologia nie są ze sobą powiązane. Są natomiast spójne, jeżeli chodzi o narzędzia poznania, do których zalicza się klasyczny, tj. arystotelesowski schemat racjonalności. M.A. Krąpiec (1967, s. 887) pisze w podsumowaniu: „Religia jako religia i poznanie racjonalne same $\mathrm{z}$ siebie są formalnie bezkolizyjne".

Obok artykułu M. A. Krąpca pojawiły się także prace Stanisława Kamińskiego (1967, s. 897-904), Antoniego B. Stępnia (1967, s. 887-897) oraz Zofii Zdybickiej (1968, s. 780-792). W tekstach tych co prawda nie można odnaleźć otwartej polemiki z Tischnerem, przyświeca im jednak bardzo zbliżona do tego podejścia konstrukcja apologetyczna ówczesnego tomizmu. Wszyscy się zgadzają co do miejsca i roli filozofii w teologii chrześcijańskiej. Prezentują również zbliżoną koncepcję filozofii jako ratio, pełnego, całościowego narzędzia opisu Objawienia. Z tekstów tych intuicyjnie wywnioskować można, iż w danym czasie krystalizowała się próba 
aktualizacji, uwspółcześnienia opisu oraz języka myśli religijnej, czyli narzędzia, którym była filozofia tomistyczna (Tischner i in. 1995, s. 29-44) ${ }^{4}$.

Wydaje się, że koniec lat 6o. ubiegłego wieku to czas aktywnej dyskusji reinterpretującej status teologii opartej na tomizmie. Podobieństwo tematyki oraz zbliżony czas oraz miejsce publikacji wskazuje na początek powoli rodzącej się dyskusji na temat statusu neotomizmu zarówno we współczesnej filozofii, jak i filozofii chrześcijańskiej. Przykładem potwierdzającym to przypuszczenie jest tekst Mieczysława Gogacza pt. Aktualne dyskusje wokół tomizmu (1967, s. 57-70). Autor opisuje w nim wewnętrzną dyskusję na temat sytuacji tomizmu w relacji do aktualnych problemów natury filozoficznej. Zdaniem M. Gogacza, tomizm wychodzi obronną ręką z większości współczesnych zarzutów, które wynikają raczej z niespójności i różnic językowych niż z błędów przedmiotowych opisywanego systemu. Jednakże na uwagę zasługuje wewnętrzna, powolna próba procesu reinterpretacji tomizmu.

W literaturze przedmiotu odnajdujemy głosy twierdzące, że realny spór o tomizm w przekazie chrześcijańskim rozpoczął się dopiero w latach 7o. XX wieku (Dymarski 1998, s. 235-245; Gabrysz 2013, s. 3-19; Jawor 2013, s. 211-227; Szary 2014, s. 221-247; Wilczek 2009, s. 52-72). Wydaje się, iż klimat filozoficzno-intelektualny końca lat 6o., w tym szczególnie liczne publikacje na temat tomizmu, nie tyle zapowiadał powszechną dyskusję, która miała dopiero nadejść, ile był raczej jej realnym i źródłowym początkiem.

Bezpośrednia dyskusja rozpoczęła się wtedy, gdy w roku 1970 ukazał się artykuł J. Tischnera pt. Schyłek chrześcijaństwa tomistycznego (1970a, s. 1-20). W swym tekście filozof ujawnia źródła sporów, z którymi boryka się współczesny katolicyzm, bezpośrednio lub pośrednio wynikających z filozofii tomistycznej. Są to np. „tomistyczna koncepcja Boga, teoria podstaw etyki, antropologia oraz koncepcja przyrody" (1970a, s. 1-5). Wszystkie te przykłady, zdaniem autora, są źródłem ataków i dyskusji z katolicyzmem. Najistotniejsze jest jednak to, iż ich powodem nie jest realny problem podlegający dyskusji, lecz niezmienny kształt systemu tomistycznego. Tekst J. Tischnera traktuje o krytyce tomizmu jako teorii opisującej myśl chrześcijańską, która popada z jednej strony w redukcjonizm, z drugiej zaś obarczona jest wewnętrzną antynomią (1970a, s. 1-5). Redukcjonizm wyraża się zarówno w zamkniętym języku, jak i w specyficznej metodzie poznania, czyli teologii spekulatywnej. Problem języka polega na tym, iż formy pojęciowe odziedziczone po Arystotelesie i św. Tomaszu nie mogą obecnie w sposób zrozumiały przedstawić istoty współczesnego chrześcijaństwa. Do tego dochodzi jeszcze metoda opisu,

4 Należy jednak zaznaczyć, że otwarta dyskusja na temat roli i wpływu filozofii na przekaz myśli chrześcijańskiej (katolickiej) mogła zaistnieć dopiero po rozstrzygnięciach Soboru Watykańskiego II (1962-1965). Tradycja tomistyczna do tego czasu stanowiła jedyny wewnętrzny język teologii katolickiej. Sobór wprowadził wolność w zakresie doboru języka opisu filozoficznego dla objawienia chrześcijańskiego. 
która wiąże się bezpośrednio z wewnętrzną sprzecznością w obrębie chrześcijaństwa, szczególnie katolicyzmu. Błąd popełnił już św. Tomasz, który zespolił myśl racjonalną Arystotelesa z myślą Objawioną. Zespolił, czyli zastosował metodę analizy filozoficznej do prezentacji i zrozumienia pełni Objawienia chrześcijańskiego (Tischner 1970a, s. 5-7). Nie musiałoby to doprowadzić do redukcjonizmu poznawczego, gdyby tomizm nie stał się bezalternatywnym systemem opisującym chrześcijaństwo na wieki (Tischner 1970a, s. 6-9).

Podstawą systemu, a przez to głównym problemem, zdaniem J. Tischnera, jest kształt teologii spekulatywnej. To wewnętrzna logika teologii spekulatywnej stoi w sprzeczności z logiką Objawienia. Dzieje się tak, gdyż metoda tomistyczna łączy w sobie dwie zasadniczo różne struktury logiczne: metafizyczną i aksjologiczną. Pierwsza związana jest ze schematem od zasady do wniosku - czyli logiką - pewną racjonalizacją i wnioskowaniem w obrębie myślenia religijnego. Druga związana jest ze schematem jakościowym, kto i co uznał - czyli chrystologią - w której mniej istotne jest to, w jaki sposób i dzięki czemu coś uznajemy, a najważniejsze - kto i co uznaje. W tej dwojakiej strukturze Objawienie w ramach unaukowienia zostało zredukowane do opisu metafizycznego. Aksjologia natomiast, czyli teoria wartości, która najpełniej wyraża się w języku Objawienia, została w znacznej mierze uproszczona. Tomizm, przyjmując jako priorytet zasadę opisu przez logikę, musiał niejako „na siłę” wtłoczyć w te ramy nie tylko część, lecz także całość Objawienia chrześcijańskiego, aby stać się holistycznym i spójnym systemem (Tischner 1970a, s. 9-15). Ma to bardzo poważne konsekwencje, gdyż w ten sposób opis tomistyczny zniekształca pełną myśl chrześcijańską. Istotą i sednem nie jest logika czy racjonalność Objawienia, prowadząca do wysokich abstrakcji pojęciowych, ale Objawienie poprzez osobę Jezusa Chrystusa - Jego słowa, nauka oraz życie, czyli wszystko to, co składa się na strukturę wartości. Z argumentacji tej można wnioskować, że pierwotnym dla chrześcijanina nie powinien być czysty opis czy pewna konstrukcja pojęciowo-racjonalna, której celem jest obiektywizacja treści, lecz wewnętrzne (niejako subiektywne) odzwierciedlenie życiowych wartości. Oznacza to pewne urealnienie konkretnego dobra, obecnego tu i teraz (Tischner 1970a, s. 12-15).

Kryzys czy schyłek, o którym mówił J. Tischner (1970a, s. 19-20), może być odczytany na płaszczyźnie filozoficznej i religijnej (chrześcijańskiej): „Z punktu widzenia filozofii zjawisko rozkładu systemów filozoficznych i jego konsekwencje należą do zjawisk normalnych, niebudzących zdziwienia żadnego filozofa, a przede wszystkim żadnego historyka filozofii. [...] Z punktu widzenia chrześcijaństwa rozejście się chrześcijaństwa $\mathrm{z}$ tomizmem nie powinno także budzić zdziwienia. W chrześcijaństwie podkreślało się i nadal się podkreśla, że głębia Objawienia jest tak wielka, iż byłoby zuchwałością, gdyby chciało się ją wyczerpać za pomocą jakichkolwiek ludzkich pojęć, w tym także pojęć filozoficznych".

Podsumowując powyższą rekonstrukcję, można stwierdzić, że bardzo jasno uwidacznia się antydogmatyczny i antysystemowy kierunek krytyki. Zdaniem J. Tischnera tomizm przez hermetyczny język i wewnętrzną, przede wszystkim 
ontologiczną strukturę opisu, zdezaktualizował się i popadł w głęboki redukcjonizm w obrębie opisu całości Objawienia chrześcijańskiego. Wynikiem tego jest potrzeba rewizji nie tylko filozofii tomistycznej, lecz także całej myśli chrześcijańskiej na przestrzeni XIX i XX wieku.

Jasnym zdaje się fakt, iż tak mocna, aby nie powiedzieć druzgocąca krytyka, musiała wywołać duży sprzeciw ze strony środowiska tomistycznego. Na odpowiedź nie trzeba było długo czekać. W obronie tomizmu wystąpił Andrzej Półtawski (1970, s. 991-999). Co charakterystyczne, jego polemika nie wyrażała się w opisie tomizmu, lecz w dezawuowaniu krytyki J. Tischnera. Z jednej strony A. Półtawski oskarżył go o nadinterpretację założeń teoretycznych tomizmu i teologii spekulatywnej, a w konsekwencji o tworzenie własnego wizerunku klasycznej doktryny. $\mathrm{Z}$ drugiej strony o to, iż krytyka tomizmu oparta została na mylnej koncepcji rzeczywistości, w której prymarna jest świadomość, a nie byt. W konsekwencji antropologia wynika wyłącznie z koncepcji świadomości i subiektywistycznego obrazu rzeczywistości. Do tych zarzutów dochodzi chyba zarzut najpoważniejszy, mówiący o tym, że gdy A. Półtawski (1970) określa propozycję J. Tischnera, jest to pewnego rodzaju antyracjonalizm, w obrębie którego nie jest możliwe stworzenie jednolitego systemu metafizycznego, w którym to, co naukowe i objawione wchodzi we wzajemną syntezę. Synteza ta z założenia nie ma kształtu ostatecznego, ale z pewnością jest całościowa, dzięki czemu to, co początkowo niepoznane, z biegiem czasu staje się uświadomione i zrozumiałe.

W podobny ton krytyki uderza głos Antoniego B. Stępnia (1970, s. 999-1001), który zarzuca J. Tischnerowi nie tyle nadinterpretację, ile nieznajomość tzw. zdrowego tomizmu i opisanie tylko pewnych jego wypaczeń. Pojawia się także zarzut kolejny, który związany jest z pewną subiektywną teologizacją w koncepcji fenomenologa. A. B. Stępień, podobnie jak A. Półtawski, uważa, iż w interpretacji teologicznych konsekwencji w wymiarze filozoficznym J. Tischner poszedł za daleko. Oznacza to, że zarzuty wobec tomizmu o bezpośredni determinizm formy chrześcijaństwa są chybione, gdyż tomizm tak dalece idących wpływów nie wykazuje. Nie jest wprawdzie tak, że tomizm dostosowuje do siebie pewną treść Objawienia chrześcijańskiego, przez co ją zmienia albo redukuje. Jest odwrotnie, to chrześcijaństwo, przyjmując język logiki arystotelesowskiej, w sposób przystępny staje się próbą ukazania tego, co może być ukazane. Co więcej, wszelkie próby obarczenia winą tomizmu za dawną i obecną krytykę chrześcijaństwa wydają się wielkim nieporozumieniem. Ta powszechna krytyka najczęściej wyrasta z niezrozumienia samej istoty i głębi Objawienia, a nie z oceny filozofii tomistycznej.

Zupełnie inną metodę krytyki przyjął Jacek Salij (1970, s. 1001-004), który podziela co prawda zdanie przywołanych powyżej tomistów, dodaje jednak własne argumenty zdanie na temat tego problemu. Uważa on, że istnieją dwa wymiary myśli chrześcijańskiej: metafizyczny i aksjologiczny. Zgadza się z Tischnerem, że tomizm koncentruje się na wymiarze metafizycznym, twierdzi dodaje jednak, że chrześcijaństwo w istocie opiera się na tym wymiarze, nie może więc być inaczej 
w przypadku tomizmu. Nie jest wprawdzie tak, że chrześcijaństwo nie ma wymiaru aksjologicznego - to byłoby oczywistym fałszem - lecz wymiar ten strukturalnie zawiera się w pierwotnej konstrukcji metafizycznej. Oznacza to, że obie płaszczyzny - metafizyczna i aksjologiczna - nie istnieją we wzajemnej sprzeczności, lecz pozostają we współoddziaływaniu. Aksjologia staje się pewną treścią, która z konieczności realizuje się w wymiarze metafizycznym. Innymi słowy, tomizm nie może popełniać błędu redukcjonizmu struktur aksjologicznych, struktur wartości, gdyż sensem chrześcijańskiej myśli jest tworzenie nowej rzeczywistości, nowego statusu ontycznego, który ze swej istoty, implicite, zawiera głęboką treść aksjologiczną.

Dyskusja nabrała tempa, gdy do obrony J. Tischnera włączył się Stanisław Grygiel. W artykule pt. Język filozofii a język Objawienia podkreśla on, że tomizm $\mathrm{w}$ swojej metodzie i w swojej strukturze opisu popada w konieczny redukcjonizm (Grygiel 1970, s. 1004-1007). Podobnie jak J. Tischner, S. Grygiel wyjaśnia, iż kryzys w chrześcijaństwie tomistycznym jest kwestią nie do uniknięcia. Dzieje się tak z tego powodu, że metafizyka klasyczna próbuje wtłoczyć wszelki byt w tę samą kategorię opisu. Co gorsza, opis ten dokonywany jest nie z perspektywy człowieka, lecz z perspektywy „bytu jako bytu”. Jego zdaniem, poznanie musi ukierunkować się w stronę człowieka, jemu należy poświęcić całą uwagę. Chrześcijaństwo to pochylenie się nad człowiekiem w jego własnej rzeczywistości, odnalezienie tego, co jest przynależne osobie i tylko jej. Grygiel swoje stanowisko i płaszczyznę badania opiera na założeniu antropologicznym. Dzięki człowiekowi i tylko w jego obrębie prawda może być opisana i zrozumiana. To zrozumienie jest wewnętrznym procesem, który wprost związany jest z rozwojem i kształtem świadomości człowieka. Wszystko, co poznajemy przez człowieka, rozumiane jest tu i teraz, ale także w przyszłej perspektywie. Wszelki natomiast statyczny, całościowy opis, może być tylko redukcjonizmem. Język myśli chrześcijańskiej jest głęboko osadzony w wielowymiarowym języku symbolicznym, języku człowieka i symbolu. Język zaś metafizyki klasycznej próbuje ująć w ramy wzorcowego, statycznego opisu to, co poza te ramy z natury swojej wykracza. Grygiel nie postuluje wprowadzania przestrzeni relatywnej do analiz Objawienia, lecz tworzenie opisu, który źródłowo nie będzie statyczną strukturą języka. Przede wszystkim samo narzędzie opisu nie może wyznaczać granic realizowania się danej treści, tym bardziej gdy mamy do czynienia z prawdą Objawienia chrześcijańskiego.

W 1970 roku Tischner publikuje odpowiedź na powyższą krytykę (197ob, s. 10131027). Doprecyzowuje w niej i wyjaśnia główne kwestie, które zrodziły się pod wpływem polemicznych tekstów. Po pierwsze uzasadnia, że w jego interpretacji na miejsce tomizmu, co wpisuje się w naturalny rozwój myśli ludzkiej, wkracza inna filozofia. Daje także wskazówki, że ta nowa teologizacja, jego zdaniem, może być związana z opisem o charakterze egzystencjalno-fenomenologicznym. Język filozofii bytu niejako zapomniał o człowieku obecnym tu i teraz. To człowiek żyjący w konkretnych czasach i warunkach jest adresatem prawdy chrześcijańskiej. W dalszej części wypowiedzi autor precyzyjnie opisuje, o jakim tomizmie pisał i powołuje się 
na M.A. Krąpca, aby uzasadnić własne rozumienie tomistycznej metafizyki, która przede wszystkim opiera się na analityczno-dedukcyjnej formie wnioskowania. W konsekwencji przechodzi do omówienia kolejnej kwestii, mianowicie do pojęcia teologizacji. J. Tischner porównuje to pojęcie do pojęcia dogmatyzacji i wyjaśnia istotną różnicę, jaka między nimi zachodzi. Ukazuje relacyjność teologii i filozofii, czyli struktur myślenia religijno-dogmatycznego, wobec interpretacji filozoficznej, dzięki czemu zarzut o zmianę czy wpływ koncepcji Tischnera na dogmatykę chrześcijańską przestaje być zasadny. Podkreśla, że problematyka dogmatu chrześcijańskiego nie była ani przedmiotem, ani też celem analiz opisanych w artykule. Ostatnia kwestia, którą podejmuje, to zarzut idealizmu czy subiektywizmu, czyli tworzenia własnej teorii „tischneryzmu”. Fenomenolog przeprowadza wnikliwą analizę pojęcia idealizmu ontologicznego oraz subiektywizmu. Odwołując się do Husserla, Heideggera oraz Ingardena, wyjaśnia źródłowe pochodzenie własnej - nie tyle metody, co pewnej struktury wywodu fenomenologicznego. Stara się oddalić zarzut o idealizm i subiektywizm, wskazując, iż sednem przyjętej metody nie jest wtórny opis stanów świadomościowych i na jego podstawie próba syntetyzacji, lecz bezpośrednie doświadczenie przedmiotu, które immanentnie i źródłowo jest pewną jego (tzn. tego podmiotu) syntetyzacją. Innymi słowy, język filozofii współczesnej ma pomóc w opisie tego, co tu i teraz uobecnia się w człowieku.

Kolejne dwa lata przynoszą ogólne wyciszenie sporu, choć należy zaznaczyć, iż debata między J. Tischnerem a A.B. Stępniem trwała nadal. Co prawda doprecyzowano płaszczyznę dyskusji, lecz wydaje się, iż polemika na forum ogólnym nie była już tak intensywna. Jej przedmiotem stała się szeroko rozumiana aksjologia, głównie etyka, oraz szczegółowa koncepcja filozofii Boga. W tym też czasie J. Tischner opublikował tekst, w którym dość krytycznie ustosunkował się do klasycznej tradycji (Tischner 1972, s. 305-321). W pracy tej autor podjął polemikę ze scholastyczno-tomistyczną filozofią Boga, której przeciwstawia koncepcję kartezjańską. Początkowo wyjaśnia, na jakich założeniach i przesłankach opiera się stanowisko klasyczne. Po pierwsze, Bóg jest bytem per se („przez się”), czyli Bytem bez przyczyny. Po drugie, Jego istota jest absolutnie prosta, istnienie jest jej aktem, czyli jest pełnią czystego aktu (Tischner 1972, s. 309). Po trzecie, Bóg jest bytem niezmiennym, a po czwarte, Bóg jest ostateczną racją wyjaśniającą istniejący świat. W czasach nowożytnych wszystkie te argumenty zostały po części bądź w całości zakwestionowane przez jednego filozofa - Kartezjusza (Tischner 1972). Zmienił on perspektywę opisu Absolutu-Boga, którego istotą wprawdzie jest istnienie per se, lecz jest to wpisane w wymiar nadrzędny, którym jest wolność. Byt doskonały, wolny, wchodzi w relacje z innymi bytami, tworząc wspólnotę, przez co sam może być przez te byty poznany i zrozumiany. Oznacza to, iż nie samo istnienie i nie czysta racjonalność jest tym, co dla Kartezjusza w bycie doskonałym jest najistotniejsze. Najważniejsza jest bowiem wolność Boga jako Osoby, która bezpośrednio wpływa na człowieka. „To nie rozum, lecz wolność czyni osobę osobą. Jeśli Bóg ma być Osobą, musi być przede wszystkim wolnością" (Tischner 1972, s. 313). 


\section{Spór na gruncie pedagogiki religii}

Zaprezentowany tu fragment polemiki J. Tischnera z polskim tomizmem ma kształt sporu filozoficzno-teologicznego, nie zaś czysto filozoficznego. Co więcej, tematyka, która jest przedmiotem tej dyskusji, charakteryzuje się nie tylko strukturą opisu interdyscyplinarnego, lecz obejmuje w swym zakresie szeroką przestrzeń problematyki społecznej i humanistycznej końca XX wieku. Podejście interdyscyplinarne w tym przypadku dotyczy zarówno analizy metod poznania, jak i treści przedmiotowych. Badania teologiczne i filozoficzne, w istocie tak różne, w tym przypadku pracują dla „wspólnej sprawy”. Tym, co scala oba podejścia, jest chęć jak najpełniejszego ukazania treści Objawienia chrześcijańskiego w szerokim horyzoncie intelektu, doświadczenia, intuicji itd. Podejście teologiczne i filozoficzne w tym przypadku może wydawać się zbieżne, jest to jednak tylko pozorne podobieństwo. Filozofia tomistyczna spełnia w tym przypadku dwie niejako koherentne role. Jest systemem filozoficznym, jaki na poziomie przedmiotowym oraz metodologicznym stał się także oficjalnym systemem opisu przesłania chrześcijańskiego, przez co wszedł w strukturę dyskursu teologicznego. Nie oznacza to jednak, że opis filozoficzny z opisem teologicznym w sposób dowolny został tu zespolony czy złączony.

Dobrym przykładem z wyżej przywołanej polemiki jest problematyka rozumienia istnienia Boga. Przedmiot analiz, w tym przypadku Bóg i jego istnienie, w tych dwóch porządkach nie jest tożsamy. Opis teologiczny swoje niezmienne źródło ma w Objawieniu. Filozoficzne natomiast rozumienie Boga (Absolutu) poszukuje uzasadnienia przede wszystkim poza granicami myślenia religijnego. Co prawda, dyskurs filozofii chrześcijańskiej wprowadza zasadę komparatystyki, w której jednym z najważniejszych, lecz nie jedynym kryterium interpretacji staje się Biblia. W tym przypadku ten sam przedmiot poznania, analizowany na innych płaszczyznach, z innych źródeł epistemicznych, jest odmiennym przedmiotem opisu. Dzięki temu bardziej klarowna wydaje się różnica teologicznego rozumienia Boga i filozoficznego Absolutu. Tu odsłaniają się kluczowe pytania dla kontekstu badań w obrębie pedagogiki religii, a szczególnie współczesnych praktyk edukacji religijnej: która $\mathrm{z}$ wymienionych powyżej perspektyw winna dominować w przekazie treści edukacji religijnej w społeczeństwie pluralistycznym? Czy priorytetem mają być treści teologiczne, dogmatyczne i kerygmat chrześcijański? Czy wręcz przeciwnie, punktem wyjścia musi stać się świat, człowiek, kultura? Tak widziany dualny podział z natury rzeczy jest redukcyjny, jednak właśnie w tej formie redukcji odsłania się istota współczesnego sporu w obrębie pedagogiki religii i szerzej edukacji religijnej. Czy język, struktura i treść przekazu religijnego winny być umocowane w tradycji i całościowym, systemowym oraz esencjalistycznym podejściu, aby na tej podstawie wskazywać, jak myśl chrześcijańska integruje i zespala pofragmentowany dziś świat? Czy, raczej przekaz musi wychodzić od potrzeb i dylematów współczesności (sfery profanum), aby na tej podstawie, niejako egzystencjalnie, odkrywać uniwersalność Objawienia, która wydarza się w „tu i teraz” dziejącym się 
momencie. Pytania te poruszają fundamentalne kwestie, $z$ którymi polska edukacja religijna musi się zmierzyć. To głośne wołanie nie tylko o konieczność wprowadzania szybkich zmian w sferze metodyki katechetycznej i religijnej, lecz przede wszystkim to dyskusja o strukturze i dialektyce przekazu treści chrześcijańskich. Innymi słowy, spór dotyczy sfery inkluzyjnego lub ekskluzywnego uprawiania edukacji religijnej w społeczeństwie pluralistycznym (Obrycka, Dąbrowski 2018, s. 2-18). Dobrym przykładem może być tu model przekazu treści chrześcijańskich, w których istotą Objawienia jest myśl teocentryczna (chrystocentryzm), gdzie np. natura Syna Bożego jest przedstawiana przede wszystkim jako natura samego Boga, lub model przeciwny, antropocentryczny (również chrystocentryczny), w którym eksponuje się zwłaszcza ludzką naturę Syna Bożego. W oczywisty sposób trzecim rozwiązaniem mogłaby być całościowa synteza tychże stanowisk, której egzemplifikacją jest pełen dogmat o podwójnej naturze Jezusa Chrystusa. Wydaje się to jednak niewystarczającym rozwiązaniem, gdyż pomija się wówczas kontekst pluralnej i demokratycznej struktury współczesnego społeczeństwa, które wymaga odmiennych względem tradycyjnych strategii działań edukacyjnych (Dąbrowski 2016b, s. 115-130).

Jak się zdaje, całą wielowątkową i złożona dysputę J. Tischnera z tomizmem można (dość redukcyjnie) sprowadzić do dwóch opozycyjnych różnic w interpretacji roli, jaką ma spełniać dyskurs filozoficzny w przestrzeni myślenia religijnego, a także jego zadań i celu. Dla filozofa dramatu celem podstawowym każdej filozofii, w tym filozofii, której namysł koncentruje się wokół myśli chrześcijańskiej, jest próba zrozumienia bólu człowieka i uczestniczenie $\mathrm{z}$ nim $\mathrm{w}$ jego dramacie. Jest to założenie, którego konsekwencją jest uprawianie filozofii antyesencjalistycznej, krytycznej, aby nie powiedzieć, antydogmatycznej. To pomysł budowania języka opisu i rozumienia zjawisk w ujęciu antropologicznym. Z kolei dla przedstawicieli filozofii tomistycznej (dokonując tu daleko idącej redukcji), priorytetem dociekań filozoficznych staje się potrzeba wygenerowania myśli systemowej, pewnej syntezy na poziomie metafizyki bytu. Rzecz rozstrzyga się o sferę rozumienia problematyki antropologicznej, która bądź jest centralną przestrzenią zainteresowania, bądź tylko jedną z istotnych poziomów analiz całego systemu (Dąbrowski 2016a, s. 273-279).

\section{Zakończenie}

Zaprezentowany powyżej spór J. Tischnera z tomizmem został intencjonalnie zredukowany do dyskusji o pierwszeństwie antropologii czy metafizyki w przekazie treści religijnych, roli badań nad subiektywnością i obiektywnością, dyskusji między myśleniem fragmentarycznym a całościowym, między zmiennością Heraklita a stałością Parmenidesa. Jednakże właśnie w tak uproszczonej wizji tejże polemiki najdobitniej ujawnia się jeden z najbardziej aktualnych sporów w przestrzeni współczesnej edukacji religijnej w Polsce. Jest to spór o cel, zakres oraz strukturę tejże edukacji zarówno w systemie edukacji powszechnej, jak również szerzej, na gruncie 
współczesnego społeczeństwa demokratycznego. Dyskusje wokół celu edukacji religijnej generują przede wszystkim następujące pytania: Czy główne zadania tejże edukacji kończą się na celach wyznaczonych w ramach danego wyznania czy konfesji? Czy wręcz przeciwnie, to one stają się elementami szerszego procesu autonomicznego włączania jednostki w świadomą strukturę społeczno-kulturowej egzystencji? Są to kwestie, które sprowadzają się do pytania: na ile współczesny model edukacji religijnej winien opierać się na procesach ekskluzji lub inkluzji społecznej, w których edukacja religijna z jednej strony jest narzędziem konstruowania tożsamości wyznaniowej, zaś z drugiej, narzędziem konstruowania tożsamości kulturowo-społecznej? Podział ten determinuje kształt kolejnej polemiki o tzw. zakres edukacji religijnej. Podejście pierwsze, konfesyjne i ekskluzywne, wiąże się z elitarnym i zamkniętym zakresem tejże edukacji, która posługuje się strukturą przekazu treści opartą na wewnętrznej teologii danego wyznania, przez co pogłębia hermetyczną strukturę tejże grupy. W aspekcie społecznym nie jest to zjawisko edukacyjnie korzystne, gdyż entymematycznie wyłącza się kontekst religii z pola edukacji powszechnej, sprowadzając ją jedynie na grunt wewnętrznych celów i zadań danego Kościoła. Niewątpliwą zaletą tego podejścia jest możliwość kształcenia i wychowania na głębokim oraz całościowym poziomie relacji ${ }^{5}$. Podejście drugie, kulturowe i inkluzyjne, będzie tu dokładnym przeciwieństwem pierwszego, gdyż cele tejże edukacji dalece wykraczają poza kryteria stawiane na polu danej grupy wyznaniowej, przez co problematyka stricte religijna niejako musi być korelowana i uzupełniana przez formy kształcenia ogólnego. Taki zakres edukacji religijnej jest wysoce korzystny dla społeczeństwa demokratycznego oraz edukacji publicznej, ponieważ posiada potencjał do scalania, czyli tworzenia podejścia holistycznego w edukacji (Znaniecka 2017, s. 149-178). Jednocześnie religia nie jest sprowadzana wyłącznie do sfery prywatnej człowieka, przez co jest zjawiskiem społecznym, jawnym, publicznym oraz poddawanym krytycznej analizie pedagogicznej (Dąbrowski 2012, s. 90-111).

\section{Bibliografia}

Bonowicz W. (2002). Tischner. Kraków: Znak.

Dąbrowski S. (2012). Krytyczna pedagogika religii. „Ars Educandi”, nr 9, s. 90-111. Dąbrowski S. (2016a). Pedagogika religii Józefa Tischnera. W poszukiwaniu nowego modelu edukacji religijnej. Słupsk: Wydawnictwo Naukowe Akademii Pomorskiej w Słupsku.

Dąbrowski S. (2016b). Strategie komunikacji w ruchu slow odpowiedzia na wyzwania edukacji międzykulturowej XXI wieku. „Multicultural Studies”, nr 1, s. 115-130.

5 Należy jednak pamiętać, że obok dużego potencjału model ten obciążony jest również wieloma zagrożeniami dla sfery religijnej człowieka, które w historii najczęściej prowadziły do rozwoju ekstremizmu oraz tendencji fundamentalistycznych. 
Dymarski Z. (1998). Debata księdza Józefa Tischnera ze szkołą lubelską. „Logos i Ethos", nr 1, s. 235-245.

Gabrysz J. (2013). Stanowisko Józefa Tischnera wobec tomizmu. „Tarnowskie Studia Teologiczne", nr 32, s. 3-19.

Gogacz M. (1967). Aktualne dyskusje wokót tomizmu. „Zeszyty Naukowe KUL”, nr 3, s. 59-70.

Grygiel S. (1970). Język filozofii a język Objawienia. „Znak”, nr 193-194, s. 1004-1007.

Horowski J. (2008). Pedagogika tomistyczna a pedagogika wartości. „Paedagogia Christiana" nr 21, s. 241-255.

Horowski J. (2015). Wychowanie moralne według pedagogiki neotomistycznej. Toruń: Wydawnictwo Naukowe Uniwersytetu Mikołaja Kopernika.

Jawor M. (2013). Spór Józefa Tischnera z tomizmem - między konfrontacją a dialogiem. „Filozofia Chrześcijańska”, nr 10, s. 211-227.

Kamiński S. (1967). Aparatura pojęciowa teologii a filozofia. „Znak”, nr 157-158, s. 897-904.

Krąpiec M. A. (1967). Religia a nauka. „Znak”, nr 157-158, s. 861-887.

Milerski B. (2011). Hermeneutyka pedagogiczna. Perspektywy pedagogiki religii. Warszawa: Wydawnictwo Naukowe ChAT.

Obrycka M., Dąbrowski S. (2018). Pedagogika religii jako subdyscyplina nauk o edukacji - między inkluzja a ekskluzja w badaniach edukacyjnych. „Karto-Teka Gdańska", nr 2, s. 2-18.

Półtawski A. (1970). O metodzie naukowej, pogańskim realizmie i chrześcijańskim idealizmie. „Znak”, nr 193-194, s. 991-999.

Salij J. (1970). Duch prawdy, duch wolności. „Znak”, nr 193-194, s. 1001-1004.

Stępień A. B. (1967). Filozofia jako ostateczna płaszczyzna dyskusji światopogląowych. „Znak”, nr 157-158, s. 887-897.

Stępień A. B. (1970). Przedwczesne podzwonne tomizmowi? „Znak”, nr 193-194, s. 999-1001.

Szary S. (2014). Paideia w kontekście filozoficznej polemiki ks. Józefa Tischnera $z$ Tomizmem. W: Krasnodębski M. (red.). Myśl pedagogiczna neoscholastyki i tomizmu. Warszawa: Wydawnictwo SWPR.

Tischner J. (1967). W kręgu spraw psychologii i filozofii. „Znak”, nr 151, s. 80-105.

Tischner J. (1968). Prolegomena chrześcijańskiej filozofii śmierci. „Znak”, nr 166, s. $422-440$.

Tischner J. (1970a). Schyłek chrześcijaństwa tomistycznego. „Znak”, nr 187, s. 1-20.

Tischner J. (1970b). O co właściwie chodzi? „Znak”, nr 193-194, s. 1013-1027.

Tischner J. (2002). Myślenie według wartości. Kraków: Znak.

Tischner J., Zbigniew N., Sławomir S. (1995). Świat się zmienił na lepsze - rozmowa. „Więź”, nr 11, s. 29-44.

Wadowski J. (1999). Dramat pytań egzystencjalnych: Ks. Józefa Tischnera filozofia dramatu jako próba odpowiedzi na pytania egzystencjalne. Wrocław: Papieski Fakultet Teologiczny. 
Wilczek A. (2009). W poszukiwaniu prawdy o człowieku, spór księdza Józefa Tischnera $z$ tomizmem. „Czasopismo Filozoficzne”, nr 4-5, s. 52-72.

Zambrzuski M. (2012). Cienie bez jaskini - spór M. Gogacza i J. Tischnera o charakter filozofii. W: Klimski T. A., Andrzejuk A. J. (red.). Filozofia i mistyka, Wokót myśli Mieczysława Gogacza. Warszawa: Wydawnictwo Naukowe Uniwersytetu Kardynała Stefana Wyszyńskiego.

Zdybicka Z. (1968). Tomizm a aggiornamento myśli chrześcijańskiej. „Znak”, nr 168, s. $780-792$.

Znaniecka M. (2017). Praktyki kontemplatywne w edukacji. Próba scalenia sfragmentowanego podmiotu, poznania i wspólnoty. W: Dąbrowski S., Obycka M. (red.). Edukacja, wartości, kontrowersje. Gdańsk: Wydawnictwo Naukowe Katedra.

\title{
JÓZEF TISCHNER'S POLEMIC WITH THE THOMISTIC TRADITION, AS A DISPUTE OVER THE SHAPE OF CONTEMPORARY RELIGIOUS EDUCATION IN POLAND
}

\begin{abstract}
This text is a presentation of a fragment of one of the most interesting philosophical and religious disputes between Józef Tischner and representatives of the Thomistic school in Poland. The following analysis focuses on the first phase of the dispute (19681972), but the basic goal of the work was to extract criticism and to see the arguments that may be crucial for the debate on the shape of contemporary religious education in Poland. The presentation of the substantive arguments and the philosophical and theological structure of the dispute would lead to the unveiling of the educational context that places this discussion in the space of critical pedagogy and religious analyses.
\end{abstract}

Keywords: Józef Tischner; Thomism; Neothomism; Christian philosophy; religious education; critical pedagogy of religion.

Szymon Dąbrowski - doktor nauk społecznych w dziedzinie pedagogiki, magister filozofii, socjologii i teologii. Kierownik Katedry Pracy Socjalnej na Wydziale Nauk Społecznych Akademii Pomorskiej w Słupsku. Wiceprezes Pomorskiego Towarzystwa FilozoficznoTeologicznego. Sekretarz naukowy „Czasopisma Pedagogicznego/The Journal of Pedagogy”. Redaktor naukowy czasopisma „Karto-Teka Gdańska”. Adres korespondencyjny: Akademia Pomorska w Słupsku, Wydział Nauk Społecznych, Katedra Pracy Socjalnej, ul. Bohaterów Westerplatte 64, 76-20o Słupsk. Adres e-mailowy: szymon.dabrowski@apsl.edu.pl. 